\section{International Air Transport Association (IATA)}

Founded in 1945 for inter-airline co-operation in promoting safe, reliable, secure and economical air services, IATA has approximately 240 members from 115 nations worldwide. IATA is the successor to the International Air Traffic Association, founded in The Hague in 1919, the year of the world's first international scheduled services.

Main offices: IATA Centre, Route de l'Aéroport 33, PO Box 416, CH-1215 Geneva, Switzerland. 800 Place Victoria, PO Box 113, Montreal, Quebec, Canada H4Z 1M1. 111 Somerset Road, \#14-05 Somerset Wing, Singapore 238164.

Website: http://www.iata.org

Director-General: Tony Tyler (UK).

\section{International Committee of the Red Cross (ICRC)}

The International Committee of the Red Cross (ICRC) is a Swissbased impartial, neutral and independent organization ensuring humanitarian protection and assistance for victims of war and other situations of violence.

Established in 1863, the ICRC is a founding member of the International Red Cross and Red Crescent Movement and of international humanitarian law, notably the Geneva Conventions.

The ICRC is mandated by the international community to be the guardian and promoter of international humanitarian law. It has a permanent mandate under international law to take impartial action for prisoners, the wounded and sick, and civilians affected by conflict.

The ICRC aims to ensure that civilians not taking part in hostilities are spared and protected; to visit prisoners of war and security detainees and ensure that they are treated humanely and according to recognized international standards that forbid torture and other forms of abuse; to transmit messages to and reunite family members separated by armed conflict; to help find missing persons; to offer or facilitate access to basic health care facilities; to provide food, safe drinking water, sanitation and shelter in emergencies; to promote respect for, monitor compliance with and contribute to the development of international humanitarian law; to help reduce the impact of mines and explosive remnants of war on people; and to support national Red Cross and Red Crescent Societies to prepare for and respond to armed conflict and situations of violence.

The ICRC is a global presence with offices in over 80 countries and some 12,000 staff worldwide. Its HQ is in Geneva, Switzerland.

Headquarters: 19 avenue de la Paix, CH-1202 Geneva,

Switzerland.

Website: http://www.icrc.org

President: Peter Maurer (Switzerland).

\section{Further Reading}

Forsythe, David P., The Humanitarians: The International Committee of the Red Cross. 2005

Forsythe, David P. and Rieffer-Flanagan, Barbara Ann J., The International Committee of the Red Cross: A Neutral Humanitarian Actor. 2007

Moorehead, Caroline, Dunant's Dream: War, Switzerland and the History of the Red Cross. 1998

\section{International Criminal Court (ICC)}

Origin. As far back as 1946 an international congress called for the adoption of an international criminal code prohibiting crimes against humanity and the prompt establishment of an international criminal court, but for more than 40 years little progress was made. In 1989 the end of the Cold War brought a dramatic increase in the number of UN peacekeeping operations and a world where the idea of establishing an International Criminal Court became more viable. The United Nations Conference of Plenipotentiaries on the Establishment of an International Criminal Court took place from 15 June-17 July 1998 in Rome, Italy.

Aims and Activities. The International Criminal Court is a permanent court for trying individuals who have been accused of committing genocide, war crimes and crimes against humanity, and is thus a successor to the ad hoc tribunals set up by the UN Security Council to try those responsible for atrocities in the former Yugoslavia and Rwanda. Ratification by 60 countries was required to bring the statute into effect. The court began operations on 1 July 2002 with 139 signatories and after ratification by 76 countries. By Feb. 2013 the number of ratifications had increased to 121 . Its first trial, with Thomas Lubanga facing war crimes charges for his role in the Democratic Republic of the Congo's civil war, opened on 26 Jan. 2009 and was not concluded until 14 March 2012. Lubanga was found guilty of conscripting and enlisting children under the age of 15 and using them to participate in hostilities.

Judges. The International Criminal Court's first 18 judges were elected in Feb. 2003, with six serving for three years, six for six years and six for nine years. Every three years six new judges are elected. Anthony Carmona of Trinidad and Tobago was elected in Dec. 2011 and became a judge in March 2012 but resigned in Feb. 2013 to become the country's president. At the time of going to print a successor had yet to be elected. At present the 17 judges, with the year in which their term of office is scheduled to end, are: Joyce Aluoch (Kenya, 2018); Chile EboeOsuji (Nigeria, 2021); Silvia Fernández de Gurmendi (Argentina, 2018); Robert Fremr (Czech Republic, 2021); Olga Venecia Herrera Carbuccia (Dominican Republic, 2021); Hans-Peter Kaul (Germany, 2015); Erkki Kourula (Finland, 2015); Akua Kuenyehia (Ghana, 2015); Sanji Mmasenono Monageng (Botswana, 2018); Howard Morrison (United Kingdom, 2021); Kuniko Ozaki (Japan, 2018); Song Sang-hyun (South Korea, 2015); Miriam Defensor Santiago (Philippines, 2021); Cuno Tarfusser (Italy, 2018); Ekaterina Trendafilova (Bulgaria, 2015); Anita Ušacka (Latvia, 2015); Christine Van Den Wyngaert (Belgium, 2018).

Prosecutor. Fatou Bensouda (Gambia) was unanimously elected the second prosecutor of the Court on 12 Dec. 2011 and succeeded Luis Moreno-Ocampo (Argentina) on 16 June 2012.

Headquarters: Maanweg 174, 2516 AB The Hague, Netherlands. Website: http://www.icc-cpi.int

President: Song Sang-hyun (South Korea).

\section{Further Reading}

Baker, Michael N. (ed.) International Criminal Court: Developments and U.S. Policy. 2012

Macedo, Stephen, (ed.) Universal Jurisdiction: National Courts and the Prosecution of Serious Crimes Under International Law. 2003

Mendes, Errol, Peace and Justice at the International Criminal Court: A Court of Last Resort. 2010

Schabas, William A., An Introduction to the International Criminal Court. 4th ed. 2011

Struett, Michael J., The Politics of Constructing the International Criminal Court: NGOs, Discourse, and Agency. 2008 